\title{
Lymph node metastasis in early gastric cancer
}

\section{Metástase linfonodal em câncer gástrico precoce}

\author{
Gullherme Pinto Bravo Neto, tCBC-RJ1; Elizabeth Gomes dos Santos, TCBC-RJ 2; Felipe Carvalho Victer, TCBC-RJ²; \\ Carlos Eduardo de Souza Carvalho ${ }^{3}$
}

A $B$ S T T R A C T

\begin{abstract}
Objective: to evaluate the incidence of lymph node metastasis in early gastric cancer, identifying risk factors for its development. Methods: we conducted a prospective study of patients with gastric cancer admitted to the Section of the Esophago-Gastric Surgery of the Surgery of Service HUCFF-UFRJ, from January 2006 to May 2012. Results: the rate of early gastric cancer was $16.3 \%$. The incidence of nodal metastases was $30.8 \%$ and occurred more frequently in patients with tumors with involvement of the submucosa $(42.9 \%)$, in those poorly differentiated $(36.4 \%)$, in tumors larger than $2 \mathrm{~cm}$ (33.3\%) and in type III ulcerated lesions (43.8\%). Conclusion: the incidence of lymph node metastases in patients was very high and suggests that one should keep the radicality of resection in early gastric cancer, particularly in relation to D2 lymphadenectomy, recommended for advanced gastric cancer. Conservative resections, with lymphadenectomies smaller than D2, should be performed only in selected cases, well-studied as for the risk factors of lymph node metastasis. Despite the small number of cases did not permit to relate the rate of lymph node metastasis to the risk factors considered, we noted a strong tendency for the occurrence of these metastases in the poorly differentiated, type III, larger than $2 \mathrm{~cm}$ tumors, and in the Lauren diffuse types.
\end{abstract}

Key words: Stomach neoplasms. Lymphatic metastasis. Gastrectomy. Lymph node excision. Risk factors.

\section{INTRODUCTION}

ymph node metastasis in gastric cancer is frequent and -early, and depends on many variables, amongst which the depth of invasion of the gastric wall, the degree of tumor differentiation and tumor size ${ }^{1-4}$. Thus, early tumors may have incidence of lymph node metastases ranging from $0 \%$, when restricted to the mucosa, well differentiated and less than $2 \mathrm{~cm}$ in size, to more than $30 \%$, when reaching the submucosa, being poorly differentiated and having more than $2 \mathrm{~cm}$ diameter ${ }^{5,6}$. The knowledge of the parameters of risk for these metastases, as well as the use of diagnostic procedures able to identify them in the preoperative and intraoperative periods, made possible the realization of more conservative procedures, such as endoscopic resection and smaller gastrectomies with limited lymphadenectomy, in selected cases of early gastric cancer, thus individualizing surgery of gastric adenocarcinoma and reducing treatment complications, both early and late ${ }^{7,8}$.

The objective of this study was to evaluate the incidence of lymph node metastasis in early gastric cancer $(E G C)$, identifying its risk factors for its development.

\section{METHODS}

We conducted a prospective study of patients with gastric cancer admitted to the Esophago-Gastric Section of the General Surgery Service of the Clementino Fraga Filho University Hospital, Federal University of Rio de Janeiro (HUCFF-UFRJ), from January 2006 to May 2012. All patients admitted with a diagnosis of gastric adenocarcinoma confirmed by histopathological examination of gastric tissue obtained by endoscopic biopsies fragment underwent clinical staging and imaging. Gastric cancer patients without criteria of inoperability or unresectability, confirmed by laparoscopy or laparotomy, were submitted to curative gastric resection with D2 lymphadenectomy. All patients were informed of the risks and benefits of the procedure and signed an informed consent form.

From 2008 on, with the introduction of endoscopic ultrasonography in HUCFF-UFRJ, patients with early gastric lesions suggestive of cancer at endoscopy underwent endoscopic ultrasound to confirm the degree of tumor penetration of the gastric wall and evaluation of suspect perigastric nodes. Those with echoendoscopic confirmation

1. Departament of Surgery, Faculty of Medicine, UFRJ; 2. Esophago-Gastric Section, General Surgery Service, Clementino Fraga Filho Universitary Hospital, UFRJ; 3. Service of Pathology, Clementino Fraga Filho Universitary Hospital, UFRJ. 
of early tumor without perigastric lymphadenopathy were operated and submitted to sentinel nodes research, which, when negative, provided the realization of smaller gastric resections with modified D1 lymphadenectomy, as recommended by the Japanese Society of Gastric Cancer ${ }^{9,10}$. Patients with endoscopic ultrasound doubtful as to the degree of penetration of the tumor and/or suspect perigastric lymph nodes were treated for advanced tumors. For all the patients operated the lymphadenectomy specimen was individualized as for the number of resected lymph nodes and the presence of nodal metastases.

The macroscopic appearance of the lesion was classified according to criteria of the Japanese Society of Gastric Cancer ${ }^{11}$ in types I, IIa, IIb, IIC and III. Its dimensions and microscopic features, such as cellular differentiation and Lauren classification, were evaluated in surgical specimens. The parameters used for the risk of nodal metastases configuration were: tumor size, less than or equal to $2 \mathrm{~cm}$ versus larger than $2 \mathrm{~cm}$; macroscopic classification: type I and II versu type III; degree of cell differentiation: well- or moderately differentiated versus poorly differentiated; Lauren classification: intestinal type versus diffuse type; degree of tumor penetration of the gastric wall: restricted to the mucosa (T1a) versus with involvement of the submucosa (T1b).

The staging of gastric cancer followed the criteria established by the American Joint Committee on Cancer (AJCC) in its seventh edition, $2010^{12}$.

The descriptive analysis of the observed data was presented in the form of tables, expressed by the frequency (n) and percentage (\%) for categorical data and by median, minimum and maximum for numeric data. In order to check whether there was a significant association between the variables of the lesion with the presence of metastasis, we applied: the chi-square $\left(^{2}\right)$ or Fisher exact test for comparisons of categorical (qualitative) data and the MannWhitney test (nonparametric) to compare numerical data (lesion size in $\mathrm{cm}$ ).

We applide the nonparametric method, because the size of the lesion did not show normal distribution (Gaussian distribution) due to the wide dispersion of the data and rejection of the hypothesis of normality according to the Kolmogorov-Smirnov test. The criterion for determining significance was set at $5 \%$.

\section{RESULTS}

During the study period, 160 patients with gastric cancer were admitted to staging. Of these, nine (5.6\%) were considered inoperable, 12 (7.5\%) unresectable at laparotomy, and 14 (8.8\%) were submitted to palliative gastrojejunostomy due to the presence of pyloric obstruction. The remaining 125 $(78.1 \%)$ underwent gastric resections, of which 83 $(66.4 \%)$ with curative intent, with D2 lymphadenectomy, 30 (24\%) with palliative resections for locally advanced disease without possibility of R0 resection, and 12 (9.6\%) with atypical resections and gastric D1 modified lymphadenectomy (perigastric nodes plus 7 and/or 8 and/or 9 chains) (Table 1). Among the latter, 11 were patients with early tumors without evidence of lymph node metastasis at sentinel nodes research and one had tumor in situ.

The mean number of resected lymph nodes in D2 and modified D1 lymphadenectomies was 25. Of the patients who underwent gastrectomy with D2 lymphadenectomy, D1 (palliative resections) and modified D1, 116 could be properly staged. The incidence of lymph node metastases $(\mathrm{N})$ and staging based on the degree of penetration of the tumor in the gastric wall $(T)$ can be seen in Table 2 . There was a significant association $(p<0.0001)$ between the degree of penetration of the tumor in the gastric wall $(T)$ and lymph node metastasis $(\mathrm{N}+)$. The list of patients with EGC and the tumors features, such as the degree of penetration of the gastric wall ( $\mathrm{T} 1 \mathrm{a}$ - restricted to the mucosa - or T1b - with submucosal involvement), the size of the lesion, macroscopic classification and Lauren, the degree of tumor differentiation and the presence of lymph node metastases are shown in Table 3.

The frequency of EGC was $16.3 \%$ (26 patients), $7.5 \%$ restricted to the mucosa (12 patients) and $8.8 \%$ with involvement of the submucosa (14 patients). The incidence of nodal metastases in patients with EGC was $30.8 \%$ and occurred more frequently in patients with tumors with involvement of the submucosa $(42.9 \%)$, those moderately/poorly differentiated $(38.9 \%)$, greater than $2 \mathrm{~cm}(33.3 \%)$ and ulcerated type III (43.8\%) (Tables 4 and 5). The relationship between the rates of lymph node metastasis and the variables of

Table 1 - Approach to patients without preoperative inoperability criteria.

\begin{tabular}{lll}
\hline Operable Patients & N (\%) & Surgery Performed \\
\hline $\begin{array}{l}\text { Local advanced disease without possibility of } \\
\text { RO resection }\end{array}$ & $30(24 \%)$ & Palliative Resection \\
Operable with possibility of R0 resection & $83(66.4 \%)$ & Gastrectomy with D2 lymphadenectomy \\
Early tumors without lymph node metastasis & $12(9,6 \%)$ & $\begin{array}{l}\text { Atypical Gastrectomy with limited } \\
\text { lymphadenectomy }\end{array}$ \\
\hline
\end{tabular}


Table 2 - Incidence of lymph node metastasis and $\mathrm{N}$ staging according to the degree of tumor penetration of the gastric wall (t).

\begin{tabular}{lccccc}
\hline & T4 (14) & T3 (59) & T2 (17) & T1b (14) & T1a (12) \\
\hline N 0 & $7,1 \%$ & $15,2 \%$ & $41,2 \%$ & $57,1 \%$ & $83,4 \%$ \\
N 1 & $28,6 \%$ & $11,9 \%$ & $23,5 \%$ & $14,3 \%$ & $8,3 \%$ \\
N2 & $7, \%$ & $25,4 \%$ & $23,5 \%$ & $21,4 \%$ & $8,3 \%$ \\
N3a & $28,6 \%$ & $32,2 \%$ & $11,8 \%$ & $7,1 \%$ & $0 \%$ \\
N3b & $28,6 \%$ & $15,2 \%$ & $0 \%$ & $0 \%$ & $0 \%$ \\
N+ & $92,9 \% *$ & $84,8 \% *$ & $58,8 \% *$ & $42,9 \% *$ & $16,7 \% *$ \\
\hline
\end{tabular}

${ }^{*} p<0.0001$ (significant Association between the degree of tumor penetration of the gastric wall - $T$ - and the presence of lymph node metastasis $-N$ ).

Table 3 - Tumor Characteristics and N staging of patients with EGC.

\begin{tabular}{|c|c|c|c|c|c|c|}
\hline Patient & T1 & $\operatorname{Size}(\mathrm{cm})$ & Macro Classif. & Lauren & Degree of Differentiation & $\mathrm{N}$ \\
\hline 1 & $\mathrm{~b}$ & 1.6 & III & Intestinal & Moderately Differentiated & 0 \\
\hline 2 & a & 3.5 & $\mathrm{Ilb}$ & Diffuse & Poorly Differentiated & 0 \\
\hline 3 & $\mathrm{a}$ & 0.5 & I & Intestinal & Well Differentiated & 0 \\
\hline 4 & $\mathrm{~b}$ & 2.2 & III & Intestinal & Well Differentiated & 0 \\
\hline 5 & $b$ & 1.8 & $\|\mathrm{la}+\| \mathrm{c}$ & Intestinal & Moderately Differentiated & 0 \\
\hline 6 & a & 1.5 & $\| c+I I$ & Diffuse & Poorly Differentiated & 0 \\
\hline 7 & $b$ & 1.5 & III & Diffuse & Poorly Differentiated & 0 \\
\hline 8 & $a$ & 3.0 & Ila & Intestinal & Well Differentiated & 0 \\
\hline 9 & $\mathrm{a}$ & 1.7 & I & Intestinal & Well Differentiated & 0 \\
\hline 10 & $\mathrm{~b}$ & 1.5 & Ila & Diffuse & Poorly Differentiated & 0 \\
\hline 11 & $b$ & 2.2 & III & Diffuse & Poorly Differentiated & 0 \\
\hline 12 & $a$ & 3.0 & IIb & Diffuse & Poorly Differentiated & 0 \\
\hline 13 & $\mathrm{a}$ & 3.0 & $\|\mathrm{la}+\| \mathrm{b}$ & Diffuse & Poorly Differentiated & 0 \\
\hline 14 & $b$ & 3.5 & IIb & Intestinal & Moderately Differentiated & 0 \\
\hline 15 & $\mathrm{a}$ & 2.0 & III & Intestinal & Well Differentiated & 0 \\
\hline 16 & $b$ & 1.8 & III & Intestinal & Well Differentiated & 0 \\
\hline 17 & $a$ & 4.3 & $\| l a+I I I$ & Intestinal & Well Differentiated & 0 \\
\hline 18 & $a$ & 2.0 & $\|\mathrm{Ia}+\| \|$ & Intestinal & Moderately Differentiated & 0 \\
\hline 19 & $\mathrm{~b}$ & 2.2 & III & Intestinal & Well Differentiated & 2 \\
\hline 20 & $b$ & 0.8 & IIC & Diffuse & Poorly Differentiated & 2 \\
\hline 21 & $a$ & 3.5 & III & Diffuse & Poorly Differentiated & 2 \\
\hline 22 & $a$ & 3.5 & III & Diffuse & Moderately Differentiated & 1 \\
\hline 23 & $\mathrm{~b}$ & 0.4 & III & Intestinal & Moderately Differentiated & 2 \\
\hline 24 & $b$ & 1.5 & III & Diffuse & Poorly Differentiated & $3 a$ \\
\hline 25 & $b$ & 2.0 & III & Intestinal & Moderately Differentiated & 1 \\
\hline 26 & b & 6.0 & $I I I+I I b$ & Diffuse & Poorly Differentiated & 1 \\
\hline
\end{tabular}

the lesion, such as the degree of penetration of the gastric wall $(T)$, lesion size, macroscopic classification, tumor differentiation grade and histological type of Lauren are shown in Table 6. There was no significant association between the variables of the lesion with the presence of metastases due to the small number of cases studied. There was, however, a trend toward an increased risk of metastasis in tumors larger than $2 \mathrm{~cm}$, poorly differentiated, diffuse type of Lauren, and particularly of the subgroup macroscopic classification of Type III.

\section{DISCUSSION}

In patients with gastric cancer without evidence of distant metastases, the main factor that determines the extent of the surgical procedure is the possibility of lymph node metastasis'. These are also the main prognostic factor in EGC, especially when one considers that metastasis to other sites are very rare ${ }^{13}$. The incidence of these lymphatic implants is greater the higher the degree of penetration of the tumor in the gastric wall. Thus, in advanced tumors, the rate of lymph node metastases ranges from about $50 \%$, 
Table 4 - Lymph node metastasis and N staging according to $T$, size of the lesion, macrocospic classification, degree of tumoral differentiation and histological type of Lauren.

\begin{tabular}{|c|c|c|c|c|c|c|}
\hline $\mathrm{T}$ & & $\sqrt{+}$ & N 1 & $\mathrm{~N} 2$ & & N3 \\
\hline T1a & $2 / 12$ & $(16.7 \%)$ & $1 / 12 \quad(8.3 \%)$ & $1 / 12 \quad(8.3 \%)$ & 0 & \\
\hline $\mathrm{T} 1 \mathrm{~b}$ & $6 / 14$ & $(42.9 \%)$ & $2 / 14 \quad(14.3 \%)$ & $3 / 14(21.4 \%)$ & $1 / 14$ & $(7.1 \%)$ \\
\hline Size of the lesio & & & & & & \\
\hline$<\mathrm{ou}=2 \mathrm{~cm}$ & $4 / 14$ & $(28.6 \%)$ & $1 / 14 \quad(7.1 \%)$ & $2 / 14(14.3 \%)$ & $1 / 14$ & $(7.1 \%)$ \\
\hline$>2 \mathrm{~cm}$ & $4 / 12$ & $(33.3 \%)$ & $2 / 12 \quad(16.7 \%)$ & $2 / 12(16.7 \%)$ & 0 & \\
\hline Macrosc. Classif & & & & & & \\
\hline Types I and || & $1 / 10$ & $(10 \%)$ & 0 & $1 / 10 \quad(10 \%)$ & 0 & \\
\hline Type III & $7 / 16$ & $(43.8 \%)$ & $3 / 16 \quad(18.8 \%)$ & $3 / 16(18.8 \%)$ & $1 / 16$ & $(6.2 \%)$ \\
\hline Degree of Difere & & & & & & \\
\hline Well Dif. & $1 / 8$ & $(12.5 \%)$ & 0 & $1 / 8 \quad(2.5 \%)$ & 0 & \\
\hline Mod. /Poorly Dif. & $7 / 18$ & (38.9\%) & $3 / 18 \quad(16.7 \%)$ & $3 / 18(16.7 \%)$ & $1 / 18$ & $(5.5 \%)$ \\
\hline Classif. of Laure & & & & & & \\
\hline Intestinal & $3 / 14$ & $(21.4 \%)$ & $1 / 14 \quad(7.1 \%)$ & $2 / 14(14.3 \%)$ & 0 & \\
\hline Diffuse & $5 / 12$ & (41.7\%) & $2 / 12 \quad(16.7 \%)$ & 2/12 (16.7\%) & $1 / 12$ & $(8.3 \%)$ \\
\hline
\end{tabular}

Table 5 - Relationship between rates of lymph node metastasis according to $\mathrm{T}$, size of the lesion, macroscopic classification, degree of tumor differentiation and histological type of Lauren.

\begin{tabular}{|c|c|c|c|c|c|c|}
\hline & T1 a & $\mathrm{T} 1 \mathrm{~b}$ & $\mathrm{~T} 1 \mathrm{a}<\mathrm{or}=2 \mathrm{~cm}$ & $\mathrm{~T} 1 \mathrm{a}>2 \mathrm{~cm}$ & $\mathrm{~T} 1 \mathrm{~b}<\mathrm{Ou}=2 \mathrm{~cm}$ & $\mathrm{~T} 1 \mathrm{~b}>2 \mathrm{~cm}$ \\
\hline \multicolumn{7}{|l|}{ Size of the lesion } \\
\hline$<\mathrm{or}=2 \mathrm{~cm}$ & $0 / 5$ & $4 / 9$ & - & - & - & - \\
\hline$>2 \mathrm{~cm}$ & $2 / 7$ & $2 / 5$ & - & - & - & - \\
\hline \multicolumn{7}{|l|}{ Macrosc. Classif. } \\
\hline Types I / II & $0 / 6$ & $1 / 4$ & $0 / 2$ & $0 / 4$ & $1 / 3$ & $0 / 1$ \\
\hline Type III & $2 / 6$ & $4 / 10$ & $0 / 3$ & $2 / 3$ & $3 / 6$ & $2 / 4$ \\
\hline \multicolumn{7}{|l|}{ Degree of Diferent. } \\
\hline Well Dif. & $0 / 5$ & $1 / 3$ & $0 / 3$ & $0 / 2$ & $0 / 1$ & $1 / 2$ \\
\hline Mod. /Poorly Dif. & $2 / 7$ & $5 / 11$ & $0 / 2$ & $2 / 5$ & $4 / 8$ & $1 / 3$ \\
\hline \multicolumn{7}{|l|}{ Classif. of Lauren } \\
\hline Intestinal & $0 / 6$ & $3 / 8$ & $0 / 4$ & $0 / 2$ & $2 / 5$ & $1 / 3$ \\
\hline Diffuse & $2 / 6$ & $3 / 6$ & $0 / 1$ & $2 / 5$ & $2 / 4$ & $1 / 2$ \\
\hline
\end{tabular}

when there is involvement of the muscularis propria (T2), to more than $80 \%$ when there is invasion of the serosa (T4). In these cases, surgery with curative potential is extended gastrectomy with D2 lymphadenectomy, as has long been advocated by the Japanese School, ${ }^{9,14}$.

In early tumors, ie, those in which there is invasion only of the mucousa or at maximum of the submucosa, nodal metastases rates are lower, ranging from 0 to $20.3 \%$ (mean 3.2\%) when the tumor is confined to the mucosa and from 10.2 to $33.3 \%$ (mean 19.2\%) 2 when reaching the submucosa. These variations are determined by the degree of depth of invasion in each of these layers, with the lowest rates of metastases in tumors with involvement of only the top $1 / 3$ of the mucosa $\left(m_{1}\right)$ and highest in those with invasion of the lower $1 / 3$ of the submucosa $\left(\mathrm{sm}_{3}\right)$, where the lymphatic network is richer ${ }^{15}$. Moreover, most of these lymph node metastases in EGC reach the level 1, perigastric lymph nodes, with an incidence of implants in level 2 chains ranging from $10 \%$ to $32 \%^{16,17}$. These data suggest that extensive gastric resection with broad D2 lymphadenectomy may be unnecessary for many patients with $\mathrm{EGC}^{16}$. Smaller gastrectomies, with modified D1 lymphadenectomy, have lower postoperative morbidity and mortality and provide better quality of life for this group of patients, without compromising the oncological radicality necessary for the treatment of gastric cancer ${ }^{18,19}$. The research of sentinel lymph node in EGC can help determine these nodal metastases ${ }^{20-23}$. Abe et al. proposed the combination of EGC endoscopic resection with laparoscopic lymphadenectomy in patients with EGC with risk criteria for lymph node metastasis ${ }^{24}$.

In our study, the number of patients diagnosed with EGC, 26 (16.3\%), was relatively high by Western standards, where this ratio is around $12-15 \%$, but low 
Table 6 - Relationship between rates of lymph node metastasis and injury variables: T, lesion size, macroscopic classification, tumor differentiation grade and histological type of Lauren.

\begin{tabular}{|c|c|c|c|c|c|}
\hline \multirow[t]{2}{*}{ Variable } & \multicolumn{2}{|c|}{ positive $(n=8)$} & \multicolumn{2}{|c|}{ negative $(n=18)$} & \multirow[t]{2}{*}{$p$ value $^{a}$} \\
\hline & $\mathrm{n}$ & $\%$ & $\mathrm{n}$ & $\%$ & \\
\hline \multicolumn{6}{|l|}{$\mathrm{T}$} \\
\hline T1a & 2 & 25.0 & 10 & 55.6 & 0.15 \\
\hline $\mathrm{T} 1 \mathrm{~b}$ & 6 & 75.0 & 8 & 44.4 & \\
\hline Size $(\mathrm{cm})^{b}$ & $\begin{array}{c}2.1(0.4-6.0) \\
\text { average }=2.5 \mathrm{~cm}\end{array}$ & $\begin{array}{c}2.0(0.5-4.3) \\
\text { average }=2.2 \mathrm{~cm}\end{array}$ & $0.18^{b}$ & & \\
\hline$<\mathrm{ou}=2 \mathrm{~cm}$ & 4 & 50.0 & 10 & 55.6 & 0.56 \\
\hline$>2 \mathrm{~cm}$ & 4 & 50.0 & 8 & 44.4 & \\
\hline \multicolumn{6}{|l|}{ Macrosc. Classif. } \\
\hline Types I e I| & 1 & 12.5 & 9 & 50.0 & 0.081 \\
\hline Type III & 7 & 87.5 & 9 & 50.0 & \\
\hline \multicolumn{6}{|l|}{ Degree of Difer. } \\
\hline WellDif. & 1 & 12.5 & 7 & 38.9 & 0.45 \\
\hline $\begin{array}{l}\text { Mod. /poorly Dif. } \\
\text { Lauren }\end{array}$ & 7 & 87.5 & 11 & 61.1 & \\
\hline Intestinal & 3 & 37.5 & 11 & 61.1 & 0.24 \\
\hline Difuso & 5 & 62.5 & 7 & 38.9 & \\
\hline
\end{tabular}

a Fisher exact test.

b lesion size in $\mathrm{cm}$ was expressed as median (minimum - maximum) and compared by Mann-Whitney test

compared to Eastern data ${ }^{2,25}$. The overall incidence of lymph node metastasis, $30.8 \%$ in our patients, was also very high when compared with both Eastern and Western patient populations. A German study with 126 patients with EGC showed rates of lymph node metastases around $18 \%$, ranging from $10.6 \%$ in restricted mucosal lesions to $25.3 \%$ in those with submucosal invasion ${ }^{15}$. Our rates of metastasis of tumors confined to the mucosa and with the invasion of the submucosa were $16.7 \%$ and $42.9 \%$, respectively, also high, and statistically significant difference between them. However, the degree of tumor penetration of the gastric wall is just one of the factors determining the risk of secondary lymph node implants. Other important factors are the macroscopic appearance of the lesion, tumor size, presence of lymphatic or vascular invasion and tumor differentiation grade ${ }^{1,2,3,5-7,13,15}$. Early type III tumors, or ulcerated, or mixed and partially ulcerated, display higher rates of metastasis than other types of EGC, as attested in our sample. A study of 684 patients with EGC showed a lymph node metastasis rate of $3.4 \%$ in tumors confined to the mucosa and $19 \%$ in those with invasion of the submucosa: in all patients with lymph node metastases the tumor had areas of ulceration ${ }^{16}$.

Tumor size is another risk factor for the development of lymph node metastases. The greater the injury, the greater the risk of metastases ${ }^{1-16}$. In our series, the incidence of metastasis in tumors larger than $2 \mathrm{~cm}$ was greater than in tumors smaller than $2 \mathrm{~cm}$. This parameter, although significant in univariate analyzes, is best evaluated when considered in conjunction with other risk factors for metastasis. Hölscher et al., for example, demonstrated that the probability of lymph node metastases is very low in T1a tumors smaller than $2 \mathrm{~cm}$ and in $\mathrm{T} 1 \mathrm{~b}$ lesions smaller than $1 \mathrm{~cm}^{15}$. Hirasawa et al.studied over 3800 patients and did not observe lymph node metastasis in intramucosal, well differentiated, tumors of less than $3 \mathrm{~cm}$, without angiolymphatic invasion, whether ulcerated or not ${ }^{6}$. Regarding the degree of cell differentiation, welldifferentiated tumors have a lower rate of metastasis than their moderately differentiated and poorly differentiated counterparts. Accordingly, as for Lauren's classification, the intestinal type tends to have a lower rate of lymph node metastasis than the diffuse one ${ }^{26}$. These data are confirmed in our work and can be seen in Table 5. Still from the histological point of view, tubular and papillary adenocarcinomas have better prognosis than carcinomas with signet ring cells ${ }^{13,15}$. Thus, it can be stated that the incidence of lymph node metastasis is null in tumors smaller than $2 \mathrm{~cm}$, type I (elevated), well-differentiated, intestinal type of Lauren and restricted to the mucosa, allowing the safe conduct of endoscopic resection. On the other hand, tumors poorly differentiated or undifferentiated, diffuse type of Lauren, larger than $3 \mathrm{~cm}$, even restricted to the mucosa, have rates of lymph node metastasis higher than $8 \%$, reaching more than $20 \%$ when there is involvement of the submucosa 6 . In our series, the incidence of nodal metastases in EGC in these three conditions was 38.9\%, $41.7 \%$ and $33.3 \%$, respectively.

Gotoda ${ }^{8}$ analyzed a large database of over 5000 patients who underwent gastrectomy with meticulous D2 lymphadenectomy, confidently establishing the risk of lymph node metastases in EGC and listing four groups of patients 
with a metastases rate of $0 \%$ : 1- tumor restricted to mucosa, well or moderately differentiated, without lymphatic vascular invasion, with or without ulceration, less than $3 \mathrm{~cm}$ in size; 2 - tumor restricted to the mucosa, well or moderately differentiated, without lymphatic vascular invasion, without ulceration, of any size; 3- tumor limited to the mucosa, undifferentiated or poorly differentiated, without lymphatic vascular invasion, without ulceration, less than $2 \mathrm{~cm}$ in size; and 4- tumor with superficial invasion of the submucosa $\left(\mathrm{sm}_{1}\right)$ well or moderately differentiated, without lymphatic vascular invasion, less than $3 \mathrm{~cm}$ in size.

Kwee et al., in a meta-analysis, sought to identify predictive factors of nodal metastases in $\mathrm{EGC}^{2}$. The main variables significantly associated with metastases in tumors restricted to the mucosa were: age less than 57 years, tumor located in the middle 1/3 of the stomach, large lesions, depressed and ulcerated, undifferentiated, tumors, diffuse Lauren type, and presence of lymphatic invasion. The main variables significantly associated with metastasis in tumors with invasion of the submucosa were, on their turn, were: female gender, tumor located in the lower 1/3 of the stomach, large lesions, tumors with deeper submucosal invasion, undifferentiated tumors, and lymphatic or vascular invasion.

Other aspects related to lymph node metastasis still not well understood and that may have negative impact on the survival of patients suffering from EGC undergoing resections and more conservative lymphadenectomy are the micrometastases and the skip metastases. The former are not detected in conventional histopathology, but only with immunohistochemical tests, and may therefore go unnoticed on frozen section exams, not being resected in D2 lymphadenectomy.

Kim et al. studied 90 patients staged as T1NO and found micrometastases in $10 \%$ of them ${ }^{27}$. None of them presented with tumor recurrence in more than five years of follow-up. The main independent risk factors associated with these micrometastases were the presence of lymphatic invasion and tumor size. The skip metastases, those that occur on more distant lymph nodes chains without involvement of lymph nodes closest to the tumor, bring the risk of false negativity for metastases upon research for sentinel lymph nodes. Kitagawa et al. performed a study on sentinel lymph nodes and drew attention to a $5.1 \%$ rate of skip metastasis ${ }^{28}$. Saito et al. analyzed 313 patients with lymph node metastasis in N2 chains and found 21 $(6.7 \%)$ without metastases in level 1 lymph nodes ${ }^{29}$. Most of these skip metastases concentrated on lymph node chains 7 and 8 , which should therefore be included in the lymphadenectomy of patients with negative sentinel nodes undergoing minor gastric resection with modified D1 lymphadenectomy ${ }^{10}$.

Our rate of $16.3 \%$ of EGC amongst the 160 patients studied was relatively high for Western standards, but still very low when compared with Eastern standards. The incidence of lymph node metastasis in these patients was very high and suggests that one should keep the radicality of surgery for EGC, particularly in relation to D2 lymphadenectomy, recommended for advanced gastric cancer. Conservative resections with lymphadenectomies lower than D2 should be performed only in selected cases, well studied for the risk factors of lymph node metastasis. Despite the small number of cases did not allow to establish relation between the rate of lymph node metastasis and the risk factors studied, there was a strong tendency for the occurrence of these metastases in tumors with invasion of the submucosa, larger than $2 \mathrm{~cm}$, type III, poorly differentiated and diffuse type of Lauren, as already demonstrated in other works.

\title{
R E S U M O
}

\begin{abstract}
Objetivo: avaliar a incidência de metástases linfonodais no câncer gástrico precoce identificaando fatores de risco para o surgimento destas metástases. Métodos: estudo prospectivo de pacientes portadores de câncer gástrico, internados na Seção de Cirurgia Esôfago-Gástrica do Serviço de Cirurgia Geral do HUCFF-UFRJ, no período de janeiro de 2006 a maio de 2012. Resultados: a frequência de câncer gástrico precoce foi 16,3\%. A incidência de metástases ganglionares foi 30,8\% e ocorreu com maior frequência nos pacientes portadores de tumores com comprometimento da submucosa (42,9\%), naqueles pouco diferenciados (36,4\%), nos tumores maiores que $2 \mathrm{~cm}(33,3 \%)$ e nas lesões ulceradas do tipo III (43,8\%). Conclusão: a incidência de metástases linfonodais entre os pacientes foi muito alta e sugere que se deva manter, no câncer gástrico precoce, a radicalidade das ressecções, particularmente no que se refere à linfadenectomia D2, preconizada para o câncer gástrico avançado. Ressecções conservadoras, com linfadenectomias menores que D2 devem ser realizadas apenas em casos selecionados, bem estudados quanto aos fatores de risco de metástases linfonodais. Apesar do pequeno número de casos não ter permitido relacionar o índice de metástases linfonodais aos fatores de risco estudados, pôde-se verificar uma forte tendência à ocorrência destas metástases em tumores do tipo III, maiores que $2 \mathrm{~cm}$, pouco diferenciados e do tipo difuso de Lauren.
\end{abstract}

Descritores: Neoplasias gástricas. Metástase linfática. Gastrectomia. Linfadenectomia. Fatores de risco. 


\section{REFERENCES}

1. Novotny AR, Schuhmacher C. Predicting lymph node metastases in early gastric cancer: radical resection or organ-sparing therapy? Gastric Cancer. 2008;11(3):131-3.

2. Kwee RM, Kwee TC. Predicting lymph node status in early gastric cancer. Gastric Cancer. 2008;11(3):134-48

3. Kunisaki C, Takahashi M, Nagahori $Y$, Fukushima T, Makino $\mathrm{H}_{\text {, }}$ Takagawa R, et al. Risk factors for lymph node metastasis in histologically poorly differentiated type early gastric cancer. Endoscopy. 2009;41(6):498-503.

4. Ishikawa S, Togashi A, Inoue M, Honda S, Nozawa F, Toyama E, et al. Indications for EMR/ESD in cases of early gastric cancer: relationship between histological type, depth of wall invasion, and lymph node metastasis. Gastric Cancer. 2007;10(1):35-8.

5. Li C, Kim S, Lai JF, Oh SJ, Hyung WJ, Choi WH, et al. Risk factors for lymph node metastasis in undifferentiated early gastric cancer Ann Surg Oncol. 2008;15(3):764-9.

6. Hirasawa T, Gotoda T, Miyata S, Kato Y, Shimoda T, Taniguchi H, et al. Incidence of lymph node metastasis and the feasibility of endoscopic resection for undifferentiated-type early gastric cancer. Gastric Cancer. 2009;12(3):148-52.

7. Jeong O, Ryu SY, Park YK. Accuracy of surgical diagnosis in detecting early gastric cancer and lymph node metastasis and its role in determining limited surgery. J Am Coll Surg. 2009;209(3):3027.

8. Gotoda T. Endocopic resection of early gastric cancer. Gastric Cancer. 2007;10(1):1-11.

9. Japanese Gastric Cancer Association. Treatment guidelines for gastric cancer in Japan. 2nd ed. Tokyo: Kanehara; 2004

10. Bravo Neto GP, Santos EG, Loja CAS, Carvalho FV, Neves MS Pinto MF, et al. Ressecções gástricas menores com linfadenectomia modificada em câncer gástrico precoce com linfonodo sentinela negativo. Rev Col Bras Cir. 2012;39(3):183-8

11. Japanese Gastric Cancer Association. Japanese Classification of Gastric Carcinoma - 2nd English Edition. Gastric Cancer. 1998;1:1024.

12. NCCN Clinical Practice Guidelines in Oncology (NCCN Guidelines ${ }^{\mathrm{TM}}$ ). Gastric Cancer (Including cancer in the proximal $5 \mathrm{~cm}$ of the stomach). Version 2; 2011.

13. Ohashi S, Okamura S, Urano F, Maeda M. Clinicopathologica variables associated with lymph node metastasis in submucosal invasive gastric cancer. Gastric Cancer. 2007;10(4):241-50.

14. Linhares E, Sano T, Kesley R. Linfadenectomia no câncer gástrico. In: Bravo Neto GP, Salles RARV, editores. Programa de Atualização em Cirurgia (PROACI), Ciclo 2, Módulo 1. Porto Alegre: Artmed/ Panamericana; 2005. p.61-79

15. Hölscher $A H$, Drebber U, Mönig SP, Schulte C, Vallböhmer D Bollscweiler E. Early gastric cancer: lymph node metastasis starts with deep mucosal infiltration. Ann Surg. 2009;250(5):791-7.

16. Shimoyama S, Seto Y, Yasuda H, Mafune K, Kaminishi M. Concepts, rationale, and current outcomes of less invasive surgical strategies for early gastric cancer: data from a quarter-century of experience in a single institution. World J Surg. 2005;29(1):58-65.

17. Ohdaira $H$, Nimura $H$, Mitsumori N, Takahashi N, Kashiwagi $H$ Yanaga K. Validity of modified gastrectomy combined with sentinel node navigation surgery for early gastric cancer. Gastric Cancer. 2007;10(2):117-22.
18. Yaguchi $Y$, Tsujimoto $H$, Kumano I, Takahata $R$, Matsumoto $Y$ Yoshida $K$, et al. Sentinel node navigation surgery attenuates the functional disorders in early gastric cancer. Oncol Rep 2012:27(3):643-9.

19. Ishikawa K, Arita T, Ninomiya S, Bandoh T, Shiraishi N, Kitano S Outcome of segmental gastrectomy versus distal gastrectomy for early gastric cancer. World J Surg. 2007;31(11):2204-7.

20. Dong LF, Wang LB, Shen JG, Xu CY. Sentinel lymph node biopsy predicts lymph node metastasis in early gastric cancer: a retrospective analysis. Dig Surg. 2012;29(2):124-9.

21. Kelder W, Nimura H, Takahashi N, Mitsumori N, van Dam GM Yanaga K. Sentinel node mapping with indocyanine green (ICG) and infrared ray detection in early gastric cancer: an accurate method that enables a limited lymphadenecomy. Eur J Surg Oncol 2010;36(6):552-8.

22. Ichikura T, Sugasawa $H$, Sakamoto $N$, Yaguchi $Y$, Tsujimoto $H$, Ono $S$. Limited gastrectomy with dissection of sentinel node stations for early gastric cancer with negative sentinel node biopsy. Ann Surg. 2009;249(6):942-7.

23. Ishigami S, Natsugoe S, Uenosono Y, Yanagita S, Matsumoto M, Okumura $\mathrm{H}$, et al. Usefulness of sentinel node biopsy in laparoscopic partial gastrectomy for early gastric cancer Hepatogastroenterology. 2007;54(79):2164-6.

24. Abe N, Takeuchi H, Ohki A, Yanagida O, Masaki T, Mori T, et al. Long-term outcomes of combination of endoscopic submucosa dissection and laparoscopic lymph node dissection without gastrectomy for early gastric cancer patients who have a potential risk of lymph node metastasis. Gastrointest Endosc. 2011;74(4):7927 .

25. Jacob CE, Gama-Rodrigues J, Bresciani CJC, Zilberstein B, Cecconello I. Câncer Gástrico Precoce. In: Bravo Neto GP, Salles RARV, editores. Programa de Atualização em Cirurgia (PROACI), Ciclo 2, Módulo 4. Porto Alegre: Artmed/Panamericana; 2006. p. 77-154.

26. Ito $H$, Inoue $H$, Ikeda $H$, Onimaru $M$, Yoshida A, Hosoya $T$, et al. Clinicopathological characteristics and treatment strategies in early gastric cancer: a retrospective cohort study. J Exp Clin Cancer Res. 2011:30:117

27. Kim JJ, Song KY, Hur H, Hur Jl, Park SM, Park CH. Lymph node micrometastasis in node negative early gastric cancer. Eur J Surg Oncol. 2009;35(4):409-14.

28. Kitagawa $Y$, Fujii H, Mukai M, Kubota T, Otani Y, Kitajima M Radio-guided sentinel node detection for gastric cancer. $\mathrm{Br}$ J Surg 2002;89(5):604-8.

29. Saito H, Tsujitani S, Ikeguchi M. Clinical significance of skip metastasis in patients with gastric cancer. Gastric Cancer 2007;10(2):87-91.

Received on $07 / 11 / 2012$

Accepted for publication 05/01/2013

Conflict of interest: none.

Source of funding: none.

How to cite this article:

Bravo Neto GP, Santos EG, Victer FC, Carvalho CES. Lymph node metastasis in early gastric cancer. Rev Col Bras Cir. [periódico na Internet] 2014;41(1). Disponível em URL: http://www.scielo.br/rcbc

\section{Address for correspondence:}

Guilherme Pinto Neto Bravo

Email: guilhermebravo@gmail.com 